\title{
Predictors of readmission and long length of stay in elders admitted with neurological disorders in a tertiary center: a real-world investigation
}

\author{
Preditores de readmissão hospitalar e de longo tempo de internação em idosos admitidos \\ com doenças neurológicas em centro terciário: uma investigação no mundo real
}

Aroldo BACELLAR 1,2, Bruno B. PEDREIRA', Gersonita COSTA', Telma ASSIS', Camila LOBO', Osvaldo NASCIMENTO²

\begin{abstract}
Hospital readmission and long length of stay (LOS) increase morbidity and hospital mortality and are associated with excessive costs to health systems. Objective: This study aimed to identify predictors of hospital readmission and long LOS among elders with neurological disorders (NDs). Methods: Patients $\geq 60$ years of age admitted to the hospital between January 1, 2009, and December 31, 2010, with acute NDs, chronic NDs as underpinnings of acute clinical disorders, and neurological complications of other diseases were studied. We analyzed demographic factors, NDs, and comorbidities as independent predictors of readmission and long LOS ( $\geq 9$ days). Logistic regression was performed for multivariate analysis. Results: Overall, 1,154 NDs and 2,679 comorbidities were identified among 798 inpatients aged $\geq 60$ years (mean $75.8 \pm 9.1$ ). Of the patients, 54.5\% were female. Patient readmissions were $251(31 \%)$ and 409 patients (51\%) had an LOS $\geq 9$ days (95\% confidence interval $48 \%-55 \%)$. We found no predictors for readmission. Low socioeconomic class ( $p=0.001)$, respiratory disorder $(p<0.001)$, infection $(p<0.001)$, genitourinary disorder ( $p<0.033$ ), and arterial hypertension ( $p=0.002$ ) were predictors of long LOS. Identified risks of long LOS explained $22 \%$ of predictors. Conclusions: Identifying risk factors for patient readmission are challenges for neurology teams and health system stakeholders. As low socioeconomic class and four comorbidities, but no NDs, were identified as predictors for long LOS, we recommend studying patient multimorbidity as well as functional and cognitive scores to determine whether they improve the risk model of long LOS in this population.
\end{abstract}

Keywords: Patient readmission; length of stay; nervous system diseases; multimorbidity; aged; risk factors.

\section{RESUMO}

Readmissão hospitalar e tempo longo de internação aumentam a morbidade, a mortalidade hospitalar e estão associados a custos excessivos para os sistemas de saúde. Objetivo: Este estudo almejou identificar preditores de readmissões hospitalares e longo tempo de internação (TDI) entre idosos com doenças neurológicas (DN). Métodos: Pacientes de idade $\geq 60$ anos admitidos no hospital entre 1 de janeiro de 2009 e 31 de dezembro de 2010 com DN aguda, DN crônica subjacente a transtorno clínico agudo e complicações neurológicas de outras doenças foram estudados. Nos analisamos fatores demográficos, DN e comorbidades como preditores independentes de readmissão hospitalar e TDI ( $\geq 9$ dias). Utilizamos regressão logística para analise multivariada. Resultados: Um total de 1154 DN e 2679 comorbidades foram identificadas entre 798 pacientes com idade $\geq 60$ anos (media $75.8 \pm 9.1$ ). Desses pacientes $54.5 \%$ foram mulheres. Foram 251(31\%) readmissões de pacientes e 409 (51\%) dos pacientes tiveram um TDI $\geq 9$ dias (intervalo de confiança 95\%, 48\%-55\%). Não encontramos preditores para readmissões. Baixa classe social $(p=0,001)$, distúrbio respiratório $(p<0,001)$, infecção ( $p<0,001)$, distúrbio genito-urinário $(p=0,033)$ e hipertensão arterial $(p=0,002)$ foram os preditores de longo tempo de internação. Esses fatores de risco compõem 22\% dos preditores para longo TDI. Conclusões: A identificação de fatores de risco para readmissão hospitalar é um desafio para equipes neurológicas e gestores dos sistemas de saúde. Conquanto baixa classe social e 4 comorbidades, todavia nenhuma DN, foram identificadas como preditoras para longo TDI nós recomendamos investigar multimorbidade, escores funcionais e cognitivos para saber se eles melhoram o modelo de risco para longo TDI nesta população.

Palavras-chave: Readmissão do paciente; tempo de internação; doenças do sistema nervoso; multimorbidade; idoso; fatores de risco.

\footnotetext{
'São Rafael Hospital, D’Or Institute for Research and Education (IDOR), Salvador BA, Brasil; 2Universidade Federal Fluminense, Departamento de Neurologia, Rio de Janeiro RJ, Brasil.

Aroldo Bacellar (iD) https://orcid.org/0000-0001-8452-0932

Correspondence: Aroldo Bacellar; Hospital São Rafael - Departamento de Neurologia; Av. São Rafael, 2312; CEP-41253-190 Salvador BA, Brasil. E-mail: aroldo.bacellar@prestador.hsr.com.br

Conflict of interest: There is no conflict of interest to declare.

Support: The Hospital Sao Rafael-Monte Tabor Foundation partially reimburses manuscript-processing charges to motivate research.

Received 03 October 2018; Received in final form 17 December 2018; Accepted 01 February 2019.
} 
Unplanned readmissions indicate suboptimal quality of patient care, cumulative costs, increasing morbidity, and greater hospital mortality ${ }^{1}$. Patient readmissions and long length of stay (LOS) are associated with excessive spending in health care, constituting a public health issue ${ }^{2,3}$. In addition, the aging population is associated with the burden of neurological disorders (NDs), which is a global phenomenon ${ }^{4}$. Long-term neurological conditions such as cerebrovascular diseases, epilepsy, dementia, Parkinson's disease, neuromuscular disorders, and their comorbidities are associated with patient readmissions and long $\operatorname{LOS}^{1,5,5,7,8,9,10,11}$. Inappropriate readmissions of patients with long-term neurological conditions are related to neglected opportunities to improve ambulatory care and inadequacies in hospital procedures, such as discharge planning and patient transfers ${ }^{12}$. Moreover, in elders, hospital readmissions and long LOS are very common and closely related ${ }^{13}$. In Brazil, the elderly population is increasing much faster than in developed countries, exceeding 30 million persons aged 60 years or older in $2017^{14}$. In a previously published study we found high rates of hospital readmission (31\%), and long LOS (51\%) during a two-year analysis of 798 elders hospitalized with $\mathrm{NDs}^{15}$. The present study intended to analyze demographic factors, NDs, and comorbidities in the population of elderly inpatients to identify independent predictors of readmission and long LOS.

\section{METHODS}

\section{Patients}

Patients aged 60 years or older successively admitted to the Hospital São Rafael (HSR) between January 1, 2009, and December 31, 2010, and evaluated by neurologists were enrolled. The HSR is a general tertiary teaching hospital in Salvador, Brazil, that admits patients who are clients of several private health insurance companies, as well as users of the Brazilian Unified Public Health System (SUS users).

Data were collected from electronic medical records, which made it easy to find patients with NDs in discharge lists, as well as registries of all neurological procedures. The Information Technology Department at this hospital (IT-HSR) recorded all admissions during the period of the study. Further information regarding the HSR and the method for capturing patients, including details concerning ND diagnostic assessments, can be found in our previously-published studies of the same population ${ }^{15,16}$. We enrolled elderly inpatients with NDs in this study using the following methods: 1) IT-HSR searches of NDs listed in discharge summaries and 2) IT-HSR identification of registered neurological procedures. After the IT-HSR selection, the authors carefully examined all of the written patient health records. We selected elderly inpatients with neurological symptoms based on the following criteria: 1) elderly patients with acute NDs admitted for treatment by neurologists, 2) patients admitted with acute clinical disorders owing to an underlying chronic neurological disease that needed care or follow-on therapy by a neurologist, and 3) medical or surgical patients who suffered neurological complications during their hospital stay and required consultation with a neurologist. This method ensured a corroborated data bank and captured all inpatients with NDs and their comorbidities that might have influenced readmission and long LOS. Furthermore, this process recognized patients with more than one ND and a relevant patient multimorbidity, which represents the real world of caring for elderly inpatients.

Exclusion criteria were as follows: 1) patients who were admitted by or consulted with a neurologist but who had no NDs; 2) patients whose medical records lacked important data; 3) patients with acute trauma, subarachnoid hemorrhage, central nervous system (CNS) tumor, or other neurosurgical diseases, who were directly referred to a neurosurgeon; and 4) patients who underwent neurological consultation solely for a diagnosis of brain death due to head trauma, cardiovascular arrest, neurosurgical or oncological condition that was beyond the responsibility of neurologists; and 5) patients transferred to another hospital without an established diagnosis.

\section{Demographics}

The influences of age, sex, marital status, and socioeconomic level on patient readmission and on long LOS were considered. Differences in patient readmission and long LOS with regard to socioeconomic status were estimated comparing these outcomes among SUS users with these outcomes in patients who were clients of private health insurance companies. Elderly patients who belong to families categorized as Brazilian B2 socioeconomic class (average monthly income equal to or less than equivalent to US $\$ 1,475)^{17}$ or lower socioeconomic classes use SUS ${ }^{18}$, whereas elders belonging to the Brazilian middle class (class B1 with an average family monthly income US\$2,813) and from the Brazilian upper social classes prefer to pay for private health services ${ }^{17,18,19}$.

\section{Neurological disorders}

Diagnostic criteria for NDs were based on the Tenth Revision of the International Statistical Classification of Diseases and Related Health Problems (ICD-10) ${ }^{20}$. We analyzed disease frequency, readmissions, and LOS of the following: cerebrovascular disorders representing ischemic stroke, transient ischemic attack, and spontaneous brain hemorrhage (excluding subarachnoid hemorrhage); epilepsy and acute symptomatic seizures; movement disorders including hyperkinetic disorders (Huntington's chorea, Parkinson's disease, and parkinsonism (but not cases of Parkinson's disease dementia or Lewy bodies dementia); neuromuscular disorders; CNS infections; headaches; syncope or near syncope; CNS toxic and metabolic disorders including alcoholism and other toxic or metabolic encephalopathy as well 
as acute neurologic complications of water-electrolytic balance disturbances and brain injury, represented in patients with sequelae of cardiovascular arrest. In addition, CNS neoplasms were included if patients under the care of an oncologist or neurosurgeon had consulted a neurologist for clinical treatment of NDs, such as epilepsy, headache, or cognitive disorders. Neurocognitive disorders were also included if cases of delirium and cases of dementia were diagnosed based on DSM-IV criteria ${ }^{21}$.

\section{Comorbidities}

Using the following criteria, we compiled important comorbidities that could influence the studied outcomes.

1) Arterial hypertension was diagnosed according to the criteria of the Joint National Committee on the Prevention, Detection, Evaluation and Treatment of High Blood Pressure $^{22}$. 2) Dyslipidemias were defined according to the recommendations of the National Cholesterol Education Program Expert Panel on the Detection, Evaluation and Treatment of High Blood Cholesterol in Adults (Adult Treatment Panel III) and the results of recent clinical trials $^{23}$. 3) Diabetes mellitus was diagnosed based on the follow-up report of the 2007 guidelines of the American Diabetes Association ${ }^{24}$. 4) Clinical disorders were classified according to the ICD-10 and included a) infections, which represented not only in patients who were admitted with infections but also patients with neurological symptoms who experienced infections during their hospitalization; b) neoplasms; c) chronic and acute respiratory system diseases; d) musculoskeletal diseases; e) genitourinary disorders; f) digestive disorders; g) endocrine and metabolic disorders, including water-electrolyte imbalances (hepatic insufficiency was considered a metabolic rather than a digestive disorder); h) circulatory system disorders (cardiac and peripheral vascular disorders), excluding patients with cerebrovascular diseases; and i) psychiatric disorders diagnosed based on DSM-IV criteria ${ }^{21}$. These psychiatric disorders were classified only as comorbidities of NDs, because HSR does not admit patients with a primary psychiatric diagnosis; therefore, most of the disorders were anxiety, depression, and bipolar disorder. 5) Patient multimorbidity signified patients suffering from two or more morbidities ${ }^{25}$.

\section{Readmission and long LOS}

Hospital readmissions during the two-year study period were recorded. The median LOS for the entire population was nine days; hence, hospitalizations of nine days or longer were conventionally considered long LOS.

\section{Predictors of readmission and long LOS}

Patients were dichotomized according to the incidence or no incidence of readmission. The same process was used for categorizing patients according to occurrence of long LOS. Univariate analysis of all patient characteristics was performed to find potential predictors of hospital readmission as well as to detect predictors of long LOS. Multivariate analysis of selected variables was executed thereafter.

\section{Statistics}

Quantitative variables with normal distribution were reported as their mean and standard deviation, and for variables with non-normal distribution by their median and interquartile interval. Normal variables were identified by graphic analysis and the Shapiro-Wilk test. Categorical variables were reported as frequencies and percentages.

Bivariate comparisons between groups were performed using Student's $t$-test for numerical variables with normal distribution. Categorical variables were compared by Pearson's chi-square or Fisher's exact test when necessary. We performed a stepwise backward hierarchic logistic regression for multivariate analysis to increment the power of prediction of the model. Independent variables were considered for multivariate analysis if recognized as a biological plausibility associated with the main study hypotheses and when bivariate tests showed a p-value $<0.25$ according to the algorithm proposed by Hosmer and Lemeshow ${ }^{26}$.

The dimension of the model was measured by the Akaike information criterion. The Nagelkerke $\mathrm{R}^{2}$ was employed to estimate how much the model explained outcomes, and the omnibus test of model coefficients ( $p$-value) tested whether the explained variance in a set of data was significantly greater than the unexplained variance, overall. Other tests for the dimension of the multivariable model employed were: McFadden $\mathrm{R}^{2}$, Cox and Snell $\mathrm{R}^{2}$ (ML), McKelvey and Zavoina, and Effron.

Statistical analyses were performed using SPSS (v.25, Chicago, IL), R Program (v.3.4.4), and Microsoft Excel 2016 software.

\section{Ethics}

The HSR Ethical Committee for Research approved this study (No. 8/11) on August 25, 2011. The HSR Ethical Committee for Research is certified by the National Committee for Ethics in Research, according to the Brazilian Operational Manual for Ethics Committee in Research.

\section{RESULTS}

\section{Patient demographics}

We selected 798 elders with NDs, admitted to HSR, to be studied. The mean age of these individuals was $75.8 \pm 9.1$ years (median, 76 years). The interquartile interval was 68 years (25th percentile) to 82 years (75th percentile). Women formed $55 \%$ of this population. Of this geriatric population, 464 (58\%) were married and 713 (89\%) were patients of private health services. 


\section{Readmission}

Over the two-year study period, 251 patients were readmitted to HSR, producing a readmission rate of $31 \%$ (95\%CI, 28\%-35\%). Among these patients, 101 (40\%) were readmitted more than once, resulting in an average of $1.8 \pm 1.5$ readmissions per patient.

\section{Length of stay}

The median hospital LOS for these elderly neurological inpatients was nine days, with an interquartile range between 1-20 days; thus, 409 (51\%) patients had an LOS of $\geq 9$ days (95\%CI, $48 \%-55 \%$ ).

\section{NDs and comorbidities: frequency and association with patient readmission and long LOS}

Among our older adult inpatient population, 555 (70\%) had primary NDs diagnosed by neurologists and identified in discharge summaries. The remaining 243 (30\%) patients were admitted with clinical complications of underlying neurological chronic NDs or developed neurological complications during their stay in the hospital. The latter were captured by IT-HSR examination of the physicians' billing codes. Overall, 312 (39\%) patients were affected by more than one ND, totaling 668 additional NDs that were classified as neurological comorbidities in this population. Therefore, we found 1,154 NDs among 798 elderly inpatients, which represented a mean of $1.32 \pm 0.91 \mathrm{NDs}$ (95\%CI, 1.23-1.38), with a range of 1-5 NDs per patient. Moreover, we observed a wide range of diagnostic frequency of the NDs (0.3\%-50.8\%), with cerebrovascular disease being the most common (50.8\%;
Figure 1). This study captured 2,679 comorbidities involving $90 \%$ of patients with two or more comorbidities, constituting a mean of $3.35 \pm 1.51$ (95\% CI, 3.25-3.47) and a range of $0-9$ comorbidities per patient. We found a wide range of diagnostic frequency for comorbidities (5.6\%-84.5\%), with arterial hypertension (84.5\%) and diabetes (57.5\%) being the most common comorbidities (Figure 2). Overall, for patient multimorbidity (NDs + comorbidities), the mean was $4.7 \pm 1.7$ morbidities per patient (median, 5.0).

Patient readmission rates were quite similar among all NDs and among their comorbidities. In contrast, there was significant variation in the rates of long LOS for patients with NDs as well as between their comorbidities. Figure 1 shows all NDs with disease frequency exceeding $5 \%$ and their respective rates of readmission and long LOS. Figure 2 shows these findings for their comorbidities.

\section{Predictors of readmission and long LOS}

Tables 1 and 2 compare the characteristics of patients who were readmitted to the hospital with those who were not and also of patients who stayed $\geq 9$ days (long LOS) and those who stayed $<9$ days. We found no statistically significant differences in the rates of patient readmission among independent variables, except for female sex and arterial hypertension $(\mathrm{p}<0.05)$, which were associated with reduced readmission rates. However, several variables were associated with a long LOS: age, SUS, delirium, arterial hypertension, infection, neoplasm, and genitourinary and respiratory disorders. Female sex, syncope, and headache were associated with a shorter LOS $(\mathrm{p}<0.05)$.

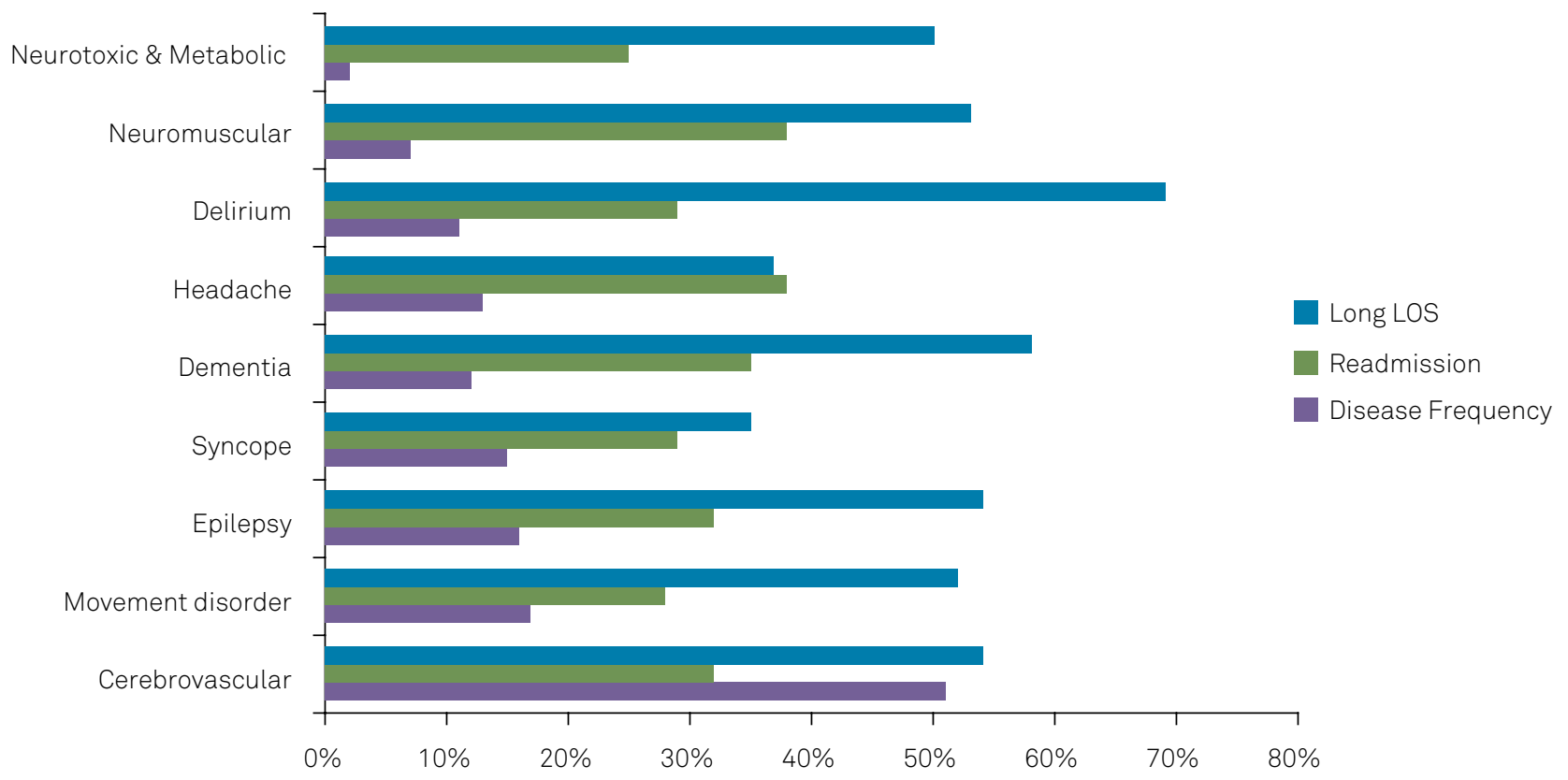

Percentages of readmission and long LOS are rates among respective disease whereas percentages of disease frequency are for 798 elders admitted with neurological disorders in a tertiary medical center. LOS: length of stay.

Figure 1. Frequency of the most-common neurological disorders and respective rate of readmission and long length of stay in elders admitted with neurological disorders in a tertiary medical center. 


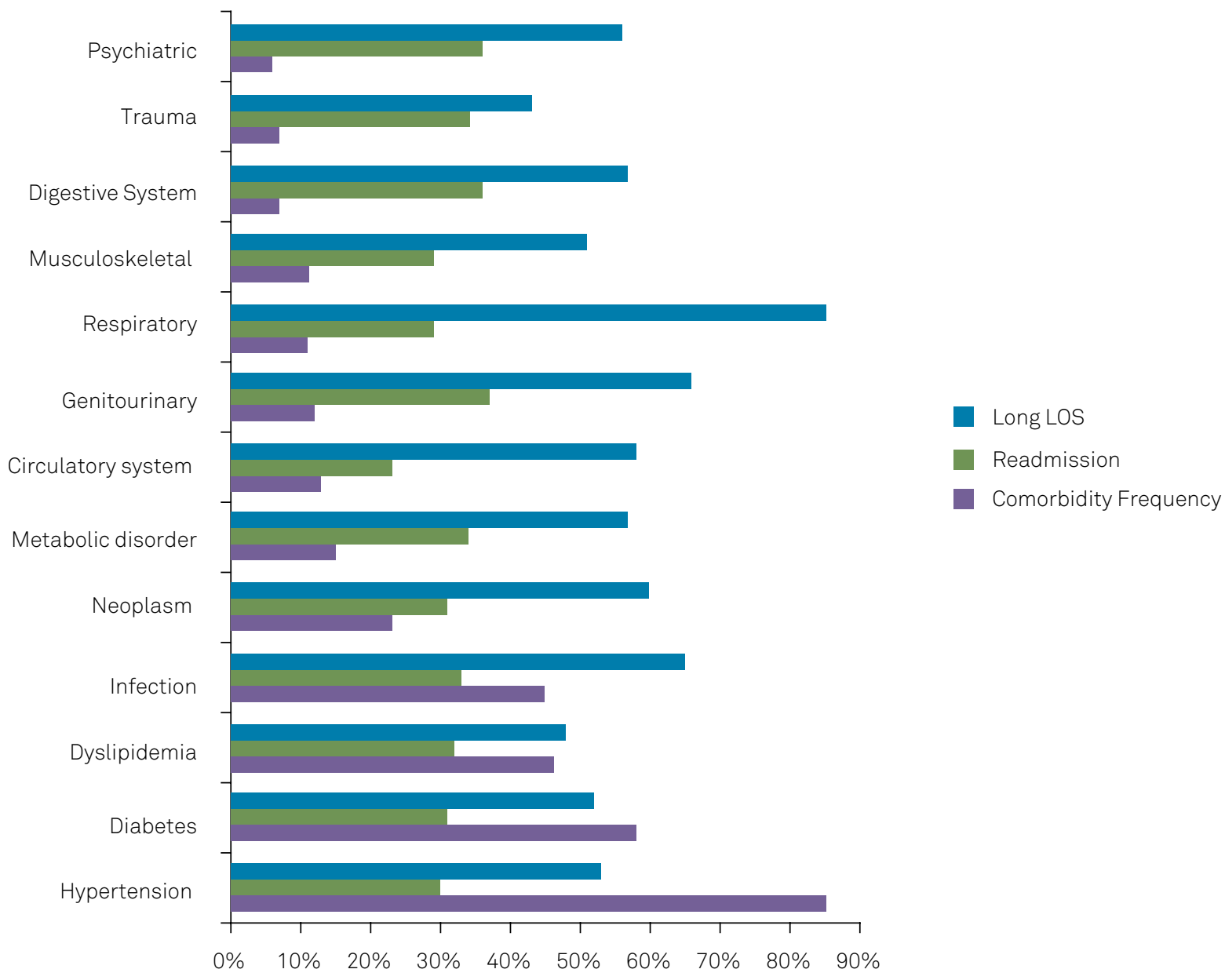

Percentages of readmission and long LOS are rates in respective comorbidity whereas percentages of disease frequency are for 798 elders admitted with neurological disorders. LOS: length of stay.

Figure 2. Frequency of comorbidities and respective rates of readmission and long length of stay in elders admitted with neurological disorders in a tertiary medical center.

Table 1. Univariate analysis of demographics and neurological disorders according to incidence of readmission and occurrence of long length of stay in elderly inpatients admitted in a tertiary medical center.

\begin{tabular}{|c|c|c|c|c|c|c|}
\hline \multirow{3}{*}{$\begin{array}{l}\text { Variable } \\
\text { All patients } n=798\end{array}$} & \multicolumn{3}{|c|}{ Readmission } & \multicolumn{3}{|c|}{ Long LOS } \\
\hline & \multirow{2}{*}{$\begin{array}{c}\text { Yes } \\
n=251\end{array}$} & \multirow{2}{*}{$\begin{array}{c}\text { No } \\
n=547\end{array}$} & \multirow{2}{*}{$p$-value } & \multirow{2}{*}{$\begin{array}{c}\text { Yes } \\
n=409\end{array}$} & \multirow{2}{*}{$\begin{array}{c}\text { No } \\
n=389\end{array}$} & \multirow{2}{*}{$p$-value } \\
\hline & & & & & & \\
\hline Age & $76.2 \pm 9.3$ & $75.5 \pm 9.0$ & 0.295 & $76.6 \pm 8.7$ & $74.9 \pm 9.4$ & 0.011 \\
\hline Female & $123(49.0)$ & $312(57.0)$ & 0.034 & $208(50.9)$ & $227(58.4)$ & 0.033 \\
\hline Married & $144(57.4)$ & $320(58.5)$ & 0.764 & $238(58.2)$ & $226(58.1)$ & 0.979 \\
\hline SUS & $33(13.1)$ & $52(9.5)$ & 0.122 & $61(14.8)$ & $24(6.2)$ & 0.001 \\
\hline Cerebrovascular & $130(51.8)$ & 275 (50.3) & 0.690 & $216(52.6)$ & $189(48.8)$ & 0.233 \\
\hline Movement disorder & $39(15.5)$ & $100(18.3)$ & 0.343 & $71(17.4)$ & $68(17.5)$ & 0.964 \\
\hline Epilepsy & $41(16.3$ & $86(15.7)$ & 0.826 & $68(16.5)$ & $59(15.2)$ & 0.573 \\
\hline Syncope & 35 (13.9) & $87(15.9)$ & 0.475 & $42(10.2)$ & $80(20.7)$ & 0.001 \\
\hline Headache & $39(15.5)$ & $63(11.5)$ & 0.114 & $36(8.8)$ & $66(17.0)$ & 0.001 \\
\hline Dementia & $34(13.5)$ & $62(11.3)$ & 0.373 & $56(13.7)$ & $40(10.3)$ & 0.139 \\
\hline Delirium & $25(10.0)$ & $61(11.2)$ & 0.712 & $59(14.4)$ & $27(6.9)$ & 0.001 \\
\hline Neuromuscular & $21(8.4)$ & $34(6.2)$ & 0.265 & $28(6.8)$ & $27(7.0)$ & 0.958 \\
\hline Neurotoxic \& metabolic & $3(1.2)$ & $9(1.6)$ & 0.864 & $6(1.5)$ & $6(1.6)$ & 0.930 \\
\hline CNS infection & $0(0)$ & $5(0.9)$ & 0.333 & $4(1.0)$ & $1(0.3)$ & 0.400 \\
\hline Brain injury & $1(0.4)$ & $2(0.4)$ & 0.999 & $1(0.2)$ & $2(0.5)$ & 0.965 \\
\hline CNS neoplasm & $0(0)$ & $2(0.4)$ & 0.999 & $1(0.2)$ & $1(0.3)$ & 0.999 \\
\hline
\end{tabular}

Data are patient numbers, and inside the parentheses are percentages (\%) within title headings.

CNS: central nervous system; LOS: length of stay. 
Table 2. Univariate analysis of comorbidities according to readmission and long length of stay in 798 elderly neurological inpatients.

\begin{tabular}{|c|c|c|c|c|c|c|}
\hline \multirow{3}{*}{$\begin{array}{l}\text { Variable } \\
\text { All patients } n=798\end{array}$} & \multicolumn{3}{|c|}{ Readmission } & \multicolumn{3}{|c|}{ Long LOS } \\
\hline & \multirow{2}{*}{$\begin{array}{c}\text { Yes } \\
n=251\end{array}$} & \multirow{2}{*}{$\begin{array}{c}\text { No } \\
n=547\end{array}$} & \multirow{2}{*}{$p$-value } & \multirow{2}{*}{$\begin{array}{c}\text { Yes } \\
n=409\end{array}$} & \multirow{2}{*}{$\begin{array}{c}\text { No } \\
n=389\end{array}$} & \multirow{2}{*}{$p$-value } \\
\hline & & & & & & \\
\hline Arterial hypertension & $200(79.7)$ & $474(86.7)$ & 0.012 & $359(87.8)$ & $315(81.0)$ & 0.008 \\
\hline Diabetes & $142(56.6)$ & $317(58.0)$ & 0.714 & $240(58.7)$ & $219(56.3)$ & 0.496 \\
\hline Dyslipidemia & $117(46.6)$ & $246(45.0)$ & 0.948 & $173(42.3)$ & $190(50.4)$ & 0.101 \\
\hline Infection & $118(47.0)$ & $242(44.2)$ & 0.465 & $235(57.5)$ & $125(32.1)$ & 0.001 \\
\hline Neoplasm & $56(22.3)$ & $125(22.9)$ & 0.865 & $108(26.4)$ & $73(18.8)$ & 0.010 \\
\hline Endocrine/metabolic & $41(16.3)$ & $81(14.8)$ & 0.578 & $69(16.9)$ & $53(13.6)$ & 0.203 \\
\hline Circulatory & $24(9.6)$ & $78(14.3)$ & 0.065 & $59(14.4)$ & $43(11.1)$ & 0.154 \\
\hline Genitourinary & $34(13.5)$ & $58(10.6)$ & 0.227 & $61(14.9)$ & $31(8.0)$ & 0.002 \\
\hline Respiratory & $25(10.0)$ & $61(11.2)$ & 0.614 & $73(17.8)$ & $13(3.3)$ & 0.001 \\
\hline Musculoskeletal & $24(9.6)$ & $62(11.3)$ & 0.453 & $44(10.5)$ & $43(11.1)$ & 0.806 \\
\hline Digestive & $21(8.4)$ & $37(6.8)$ & 0.418 & $33(8.1)$ & $25(6.4)$ & 0.372 \\
\hline Trauma & $18(7.2)$ & $35(6.4)$ & 0.684 & $23(5.6)$ & $30(7.7)$ & 0.236 \\
\hline Psychiatric & $16(6.4)$ & $29(5.3)$ & 0.542 & $25(6.1)$ & $20(5.1)$ & 0.552 \\
\hline
\end{tabular}

Data are patient numbers, and inside the parentheses are percentages (\%) within title headings.

CNS: central nervous system; LOS: length of stay.

\section{Multivariate analysis}

Despite female sex $(\mathrm{p}=0.045)$ and arterial hypertension ( $p=0.0016)$ being associated with each other in a multiple model, their logistic model was poor, according to statistics of model dimension effect: pseudo $\mathrm{R}^{2}$, Cox-Snell $\mathrm{R}^{2}$ $\left(R^{2}=0.013\right)$, Nagelkerke $R^{2}\left(R^{2}=0.18\right)$, and Hosmer-Lemeshow $\left(\mathrm{c}_{\mathrm{HL}}^{2}[2]=19.859\right), \mathrm{p}=0.007$. Thus, these findings provided unsatisfactory data for female sex and arterial hypertension in the final adjustment and, consequently, they did not predict a decrease in readmissions.

Table 3 shows multivariate analysis for long LOS: adjusted odds ratio (Exp b) with 95\% CI for the three blocks (demographics, comorbidities, and NDs) as well as p-values of variables' coefficients, according to Wald statistics. It follows that this study demonstrated that SUS users, respiratory disorders, infection, genitourinary disorders, and arterial hypertension predicted long LOS, whereas dyslipidemia, headache, and syncope were associated with a decreased probability of long LOS. Note that dyslipidemia was included in the multivariable analysis because of its relevance and in accordance with the Hosmer-Lemeshow criteria.

Accordingly, in this study, no NDs were recognized as independent risk factors for long LOS, but syncope and headache were confirmed as associated with shorter LOS. Figure 3 shows the model receiver operating characteristic and analysis of the area under the curve, which quantified the power of prediction of this model. Table 4 shows summary statistics related to the variables of hierarchical logistic regression for models according to the variables block for
Table 3. Multivariate analysis for long length of stay: adjusted odds ratio and final $p$-values according to Wald statistics.

\begin{tabular}{lcc}
\hline Variables & OR (CI95\%) & p-value \\
\hline $\begin{array}{l}\text { Demographics } \\
\text { Unified Health System } \\
\text { [SUS] }\end{array}$ & $2452(1.429-4.208)$ & 0.001 \\
\hline $\begin{array}{l}\text { Comorbidities } \\
\text { Respiratory }\end{array}$ & $5795(3.031-11.081)$ & $<0.001$ \\
\hline Infections & $2585(1.88-3.555)$ & $<0.001$ \\
\hline Genitourinary & $1720(1.044-2.834)$ & 0.033 \\
\hline Arterial Hypertension & $2056(1.316-3.212)$ & 0.002 \\
\hline $\begin{array}{l}\text { Dyslipidemia } \\
\text { Neurological disorders }\end{array}$ & $0.717(0.523-0.984)$ & 0.039 \\
\hline Headache & $0.571(0.356-0.918)$ & 0.021 \\
\hline Syncope & $0.548(0.349-0.861)$ & 0.009 \\
\hline LOS: length of stay; Cl: confidence interval &
\end{tabular}

long LOS. Additional description of the statistical analysis is available on request.

\section{DISCUSSION}

Patient readmission and long LOS are major undesirable outcomes for elderly inpatients. We studied a relatively large population of elderly inpatients with a high mean age (25\% of patients were aged 82 years or older). Our method of capturing data was uncommon, because health systems are largely 


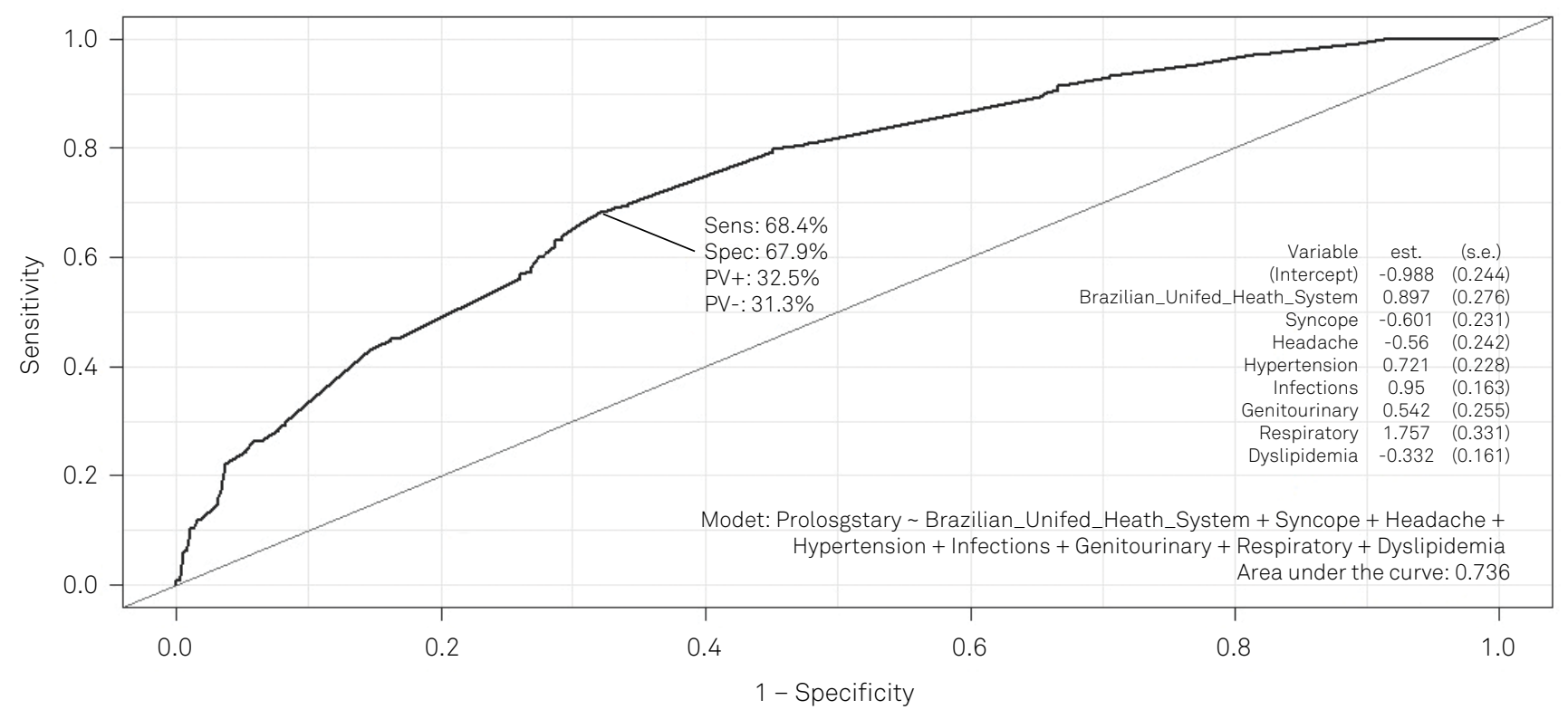

Figure 3. Receiver operating characteristic curve (ROC) for the final model.

Table 4. Hierarchical logistic regression for long length of stay related variables. The summary of statistics for models according to variable blocks.

\begin{tabular}{|c|c|}
\hline Statistics & Final model \\
\hline Akaike information criterion & 939.03 \\
\hline McFadden $\mathrm{R}^{2}$ & 0.133 \\
\hline Adj.McFadden & 0.114 \\
\hline Cox and Snell R² (ML) & 0.168 \\
\hline McKelvey.Zavoina & 0.231 \\
\hline Effron & 0.170 \\
\hline Nagelkerke R² (Cragg and Uhler's) & 0.224 \\
\hline Omnibus Test of Model Coefficientsa ( $p$-value) & $<0.001$ \\
\hline Hosmer-Lemeshow test ( $p$-value) & 0.170 \\
\hline
\end{tabular}

configured for individual disorders (i.e., patient multimorbidity was frequent in this population, which is common among elders $)^{27}$. Eighty-five (11\%) of the studied inpatients were SUS users. As SUS users belong to a lower socioeconomic class than users of private health services, we were able to compare outcomes of these two socioeconomically distinct populations. All patient characteristics were associated with a fairly high uniform rate of hospital readmission including NDs. Notwithstanding the high rate of patient readmission in this population, neither the isolated diagnosis of NDs nor their comorbidities were recognized as predictors for readmission. Other risk factors for readmission in this population should be examined, such as lack of appropriate follow-up (post-discharge suboptimal care) and social or additional factors as cited for other patients ${ }^{28,29}$. As expected, headache, syncope, and dyslipidemia were associated with reduced risk of long $\operatorname{LOS}^{30-32}$. Being an SUS user was a significant predictor of long LOS, because these patients are likely to be more severely affected by chronic disorders owing to inequalities in access to health care ${ }^{33}$. Long LOS has been noted in other low-income populations of neurological patients ${ }^{34}$. Hence, strategies for better access to primary care could ultimately reduce the LOS in Brazilian hospitals, as only $24 \%$ of Brazil's population use private health services ${ }^{35}$. Despite the fact that no ND predicted a long LOS, several comorbidities such as respiratory disorder, infection, genitourinary disorder, and arterial hypertension were associated with long LOS in this population. Patients suffering from acute and chronic respiratory disorders represented only $11 \%$ of comorbidities, but the vast majority (85\%) was associated with long LOS, indicating respiratory disorders are a strong predictor for this outcome. These results corroborate that long LOS is common in patients admitted with acute or chronic respiratory disorders ${ }^{36}$. Infections were numerous, affecting almost half of the patients, and predicted long LOS in this population. Infections are common in neurological units, particularly urinary infection by gram-negative bacteria, blood infections, skin and soft tissue infections, as well as respiratory system infections ${ }^{37}$. Genitourinary disorders were also frequent among this elderly population, especially kidney diseases. Kidney disorders are common causes of long LOS, principally when associated with sepsis and cardiovascular disorders ${ }^{38}$. Arterial hypertension was the most common comorbidity and a strong predictor for long LOS in this population, and it may be due to patients (elders) suffering from long-term arterial hypertension ${ }^{39}$. Arterial hypertension is a long-lasting disorder, and its control depends on adequate primary care, which is underprovided in Bahia, northeastern Brazil ${ }^{40}$. Comorbidities were the leading risk for long LOS in these elderly neurological patients; thus, patient multimorbidity needs to be better studied in this population. Patient multimorbidity is a matter 
of concern to health services, as health systems are configured for individual disease rather than multimorbidity ${ }^{27}$.

Overall, the studied variables accounted for $22 \%$ of the predictors of long LOS, indicating that a prospective study is needed that includes other risks, such as patient multimorbidity, nutrition status, and cognitive and functional scores, as stated for other elderly populations ${ }^{41}$.

\section{Limitations of this study}

This was a retrospective study, and we examined only the outcome of readmission to the same hospital over a maximum two-year period. Furthermore, these patients were studied before restructuring of and improvements to the HSR neurology department, which recently incorporated a neurological intensive care unit.

\section{Strengths of this study}

The number of elderly inpatients in this sample and the method used for searching NDs and comorbidities could be considered relatively robust; for more than 20 years, HSR has been one of the most important reference centers for neurology in northeast Brazil.

\section{CONCLUSIONS}

This study found no predictors for patient readmission among analyzed characteristics in elderly neurological inpatients. We suggest collaboration involving hospital neurology teams, home care stakeholders, and outpatient coordinators to study other possible risk factors and post-discharge measures to prevent patient readmissions.

Social deprivation and several comorbidities accounted for $22 \%$ of the predictors of long LOS in this particular population. Conversely, NDs were not a risk factor for long LOS. Therefore, improvements in the model of risk for long LOS ought to be attempted, including study of other patient characteristics such as patient multimorbidity and functional and cognitive scores as identified in other elderly populations.

\section{Acknowledgments}

We acknowledge Prof. Luis Correia for scientific support and Lucas E. F. Oliveira for performing statistical analysis.

\section{References}

1. Wong EL, Cheung AW, Leung MC, Yam CH, Chan FW, Wong FY, et al. Unplanned readmission rates, length of hospital stay, mortality, and medical costs of ten common medical conditions: a retrospective analysis of Hong Kong hospital data. BMC Health Serv Res. 2011 Jun;11(1):149. https://doi.org/10.1186/1472-6963-11-149

2. Zook CJ, Savickis SF, Moore FD. Repeated hospitalization for the same disease: a multiplier of national health costs. Milbank Mem Fund Q Health Soc. 1980;58(3):454-71. https://doi.org/10.2307/3349734

3. Ishak KJ, Stolar M, Hu MY, Alvarez P, Wang Y, Getsios D, et al. Accounting for the relationship between per diem cost and LOS when estimating hospitalization costs. BMC Health Serv Res. 2012 Dec;12(1):439. https://doi.org/10.1186/1472-6963-12-439

4. Group GB; GBD 2015 Neurological Disorders Collaborator Group. Global, regional, and national burden of neurological disorders during 1990-2015: a systematic analysis for the Global Burden of Disease Study 2015. Lancet Neurol. 2017 Nov;16(11):877-97. https://doi.org/10.1016/S1474-4422(17)30299-5

5. Fletcher P, Leake A, Marion MH. Patients with Parkinson's disease dementia stay in the hospital twice as long as those without dementia. Mov Disord. 2011 Apr;26(5):919. https://doi.org/10.1002/mds.23573

6. Koch S, Spuler S, Deja M, Bierbrauer J, Dimroth A, Behse F, et al. Critical illness myopathy is frequent: accompanying neuropathy protracts ICU discharge.J Neurol Neurosurg Psychiatry. 2011 Mar;82(3):287-93. https://doi.org/10.1136/jnnp.2009.192997

7. Naidech AM, Beaumont JL, Rosenberg NF, Maas MB, Kosteva AR, Ault ML, et al. Intracerebral hemorrhage and delirium symptoms. Length of stay, function, and quality of life in a 114-patient cohort. Am J Respir Crit Care Med. 2013 Dec;188(11):1331-7. https://doi.org/10.1164/rccm.201307-12560C

8. Daiello LA, Gardner R, Epstein-Lubow G, Butterfield K, Gravenstein S Association of dementia with early rehospitalization among Medicare beneficiaries. Arch Gerontol Geriatr. $2014 \mathrm{Jul}-$ Aug;59(1):162-8. https://doi.org/10.1016/j.archger.2014.02.010
9. Rocha MS, Almeida AC, Abath Neto O, Porto MP, Brucki SM. Impact of stroke unit in a public hospital on length of hospitalization and rate of early mortality of ischemic stroke patients. Arq Neuropsiquiatr. 2013 Oct;71(10):774-9. https://doi.org/10.1590/0004-282X20130120

10. Lewsey J, Ebueku O, Jhund PS, Gillies M, Chalmers JW, Redpath $A$, et al. Temporal trends and risk factors for readmission for infections, gastrointestinal and immobility complications after an incident hospitalisation for stroke in Scotland between 1997 and 2005. BMC Neurol. 2015 Jan;15(1):3. https://doi.org/10.1186/s12883-014-0257-1

11. André C, Py MO, Mariño RG. [Causes of unjustified hospital stay following cerebral infarction]. Arq Neuropsiquiatr. 1997 Sep;55(3B):569-72. https://doi.org/10.1590/S0004-282X1997000400009

12. Hammond CL, Phillips MF, Pinnington LL, Pearson BJ, Fakis A. Appropriateness of acute admissions and last in-patient day for patients with long term neurological conditions. BMC Health Serv Res. 2009 Feb;9(1):40. https://doi.org/10.1186/1472-6963-9-40

13. García-Pérez L, Linertová R, Lorenzo-Riera A, Vázquez-Díaz JR, Duque-González B, Sarría-Santamera A. Risk factors for hospital readmissions in elderly patients: a systematic review. QJM. 2011 Aug;104(8):639-51. https://doi.org/10.1093/qjmed/hcr070

14. Agencia IBGE Noticias. Numero de idosos cresce $18 \%$ em cinco anos e ultrapassa 30 milhoes em 2017. 2018 Apr 26. Available from:https://agenciadenoticias.ibge.gov.br/agencianoticias/2012agencia-de-noticias/noticias/20980-numero-deidosos-cresce

15. Bacellar A, Pedreira BB, Costa G, Assis T. Frequency, associated features, and burden of neurological disorders in older adult inpatients in Brazil: a retrospective cross-sectional study. BMC Health Serv Res. 2017 Jul;17(1):504. https://doi.org/10.1186/s12913-017-2260-x 
16. Bacellar A, Assis T, Pedreira BB, Costa G, Nascimento OJ. Hospital mortality among elderly patients admitted with neurological disorders was not predicted by any particular diagnosis in a tertiary medical center. Open Neurol J. 2018 Jan;12(1):1-11. https://doi.org/10.2174/1874205X01812010001

17. Brazilian Market Research Association. Critério de Classificação Econômica Brasil. Brazilian Criteria 2015 and social class distribution update for 2016. 2016. [Cited 2016 Apr 16]. Available from: http://www.abep.org/Servicos/Download.aspx?id=13

18. Bós AM, Bós AJ. [Determinants of elders' choice between private and public health care providers]. Rev Saude Publica. 2004 Feb;38(1):113-20. Portuguese. https://doi.org/10.1590/S0034-89102004000100016

19. Boccolini CS, Souza Junior PR. Inequities in Healthcare utilization: results of the Brazilian National Health Survey, 2013. Int J Equity Health. 2016 Nov;15(1):150. https://doi.org/10.1186/s12939-016-0444-3

20. van Drimmelen-Krabbe JJ, Bradley WG, Orgogozo JM, Sartorius N. The application of the International Statistical Classification of Diseases to neurology: ICD-10 NA. J Neurol Sci. 1998 Nov;161(1):2-9. https://doi.org/10.1016/S0022-510X(98)00217-2

21. American Psychiatric Association. Diagnostic and statistical manual of mental disorders, 4th ed. Washington, DC: American Psychiatric Association; 1994

22. Chobanian AV, Bakris GL, Black HR, Cushman WC, Green LA, Izzo $J \mathrm{~J} J$ r, et al. The Seventh Report of the Joint National Committee on Prevention, Detection, Evaluation, and Treatment of High Blood Pressure: the JNC 7 report. JAMA. 2003 May;289(19):2560-72. https://doi.org/10.1001/jama.289.19.2560

23. Grundy SM, Cleeman JI, Merz CN, Brewer HB Jr, Clark LT, Hunninghake DB, et al. Implications of recent clinical trials for the National Cholesterol Education Program Adult Treatment Panel III Guidelines. J Am Coll Cardiol. 2004 Aug;44(3):720-32. https://doi.org/10.1016/j.jacc.2004.07.001

24. Genuth S, Alberti KG, Bennett P, Buse J, Defronzo R, Kahn $R$, et al. Follow-up report on the diagnosis of diabetes mellitus. Diabetes Care. 2003 Nov;26(11):3160-7. https://doi.org/10.2337/diacare.26.11.3160

25. Oni T, McGrath N, BeLue R, Roderick P, Colagiuri S, May CR, et al. Chronic diseases and multi-morbidity: conceptual modification to the WHO ICCC model for countries in health transition. BMC Public Health. 2014 Jun;14(1):575. https://doi.org/10.1186/1471-2458-14-575

26. Hosmer DW Jr, Lemeshow S. Applied logistic regression. 2nd ed. New York: Wiley-Interscience; 2000

27. Barnett K, Mercer SW, Norbury M, Watt G, Wyke S, Guthrie B. Epidemiology of multimorbidity and implications for health care, research, and medical education: a crosssectional study. Lancet. 2012 Jul;380(9836):37-43. https://doi.org/10.1016/S0140-6736(12)60240-2

28. Yam CH, Wong EL, Chan FW, Leung MC, Wong FY, Cheung AW, et al. Avoidable readmission in Hong Kong: system, clinician, patient or social factor? BMC Health Serv Res. 2010 Nov;10(1):311. https://doi.org/10.1186/1472-6963-10-311
29. Hesselink G, Zegers M, Vernooij-Dassen M, Barach P, Kalkman C, Flink M, et al. Improving patient discharge and reducing hospital readmissions by using Intervention Mapping. BMC Health Serv Res. 2014 Sep;14(1):389. https://doi.org/10.1186/1472-6963-14-389

30. Knox J, Chuni C, Naqvi Z, Crawford P, Waring W. Presentations to an acute medical unit due to headache: a review of 306 consecutive cases. Acute Med. 2012;11(3):144-9.

31. Shiyovich A, Munchak I, Zelingher J, Grosbard A, Katz A. Admission for syncope: evaluation, cost and prognosis according to etiology. Isr Med Assoc J. 2008 Feb;10(2):104-8

32. Delgado-Rodríguez M, Medina-Cuadros M, Gómez-Ortega A, Martínez-Gallego G, Mariscal-Ortiz M, Martinez-Gonzalez MA, et al. Cholesterol and serum albumin levels as predictors of cross infection, death, and length of hospital stay. Arch Surg. 2002 Jul;137(7):805-12. https://doi.org/10.1001/archsurg.137.7.805

33. Garcia-Subirats I, Vargas I, Mogollón-Pérez AS, De Paepe P, Silva MR, Unger JP, et al. Inequities in access to health care in different health systems: a study in municipalities of central Colombia and north-eastern Brazil. Int J Equity Health. 2014 Jan;13(1):10. https://doi.org/10.1186/1475-9276-13-10

34. Corrao G, Rea F, Merlino L, Mazzola P, Annoni F, Annoni G. Management, prognosis and predictors of unfavourable outcomes in patients newly hospitalized for transient ischemic attack: a real-world investigation from Italy. BMC Neurol. 2017 Jan;17(1):12. https://doi.org/10.1186/s12883-017-0796-3

35. Instituto Brasileiro de Geografia e Estatística - IBGE. Brazilian health services availability and utilization: a population-based study. (1998, Dec 15). Available from:http://www.ibge.gov.br/home/ estatistica/populacao/trabalhoerendimento/pnad98/saude/ analise.shtm

36. Gadre SK, Duggal A, Mireles-Cabodevila E, Krishnan S, Wang $\mathrm{XF}$, Zell K, et al. Acute respiratory failure requiring mechanical ventilation in severe chronic obstructive pulmonary disease (COPD). Medicine (Baltimore). 2018 Apr; 97(17): e0487. https://doi.org/10.1097/MD.0000000000010487

37. Djordjevic Z, Jankovic S, Gajovic O, Djonovic N, Folic N, Bukumiric Z. Hospital infections in a neurological intensive care unit: incidence, causative agents and risk factors. J Infect Dev Ctries. 2012 Nov;6(11):798-805. https://doi.org/10.3855/jidc.2659

38. Yong TY, Fok JS, Ng PZ, Hakendorf P, Ben-Tovim DI, Roberts S, et al. The significance of reduced kidney function among hospitalized acute general medical patients. QJM. 2013 Jan;106(1):59-65. https://doi.org/10.1093/qjmed/hcs192

39. Sanders JS, Skipworth JR, Cooper JA, Brull DJ, Humphries $\mathrm{SE}$, Mythen $\mathrm{M}$, et al. Duration of preceding hypertension is associated with prolonged length of ICU stay. Int J Cardiol. 2012 May;157(2):180-4. https://doi.org/10.1016/j.ijcard.2010.12.011

40. Aleluia IR, Medina MG, Almeida PF, Vilasbôas AL. Care coordination in primary health care: an evaluative study in a municipality in the Northeast of Brazil. Cien Saúde Colet. 2017 Jun;22(6):1845-56. https://doi.org/10.1590/1413-81232017226.02042017

41. Campbell SE, Seymour DG, Primrose WR. A systematic literature review of factors affecting outcome in older medical patients admitted to hospital. Age Ageing. 2004 Mar;33(2):110-5. https://doi.org/10.1093/ageing/afh036 